\title{
Cross-national Reconstruction of Managerial Practices: TQM in Turkey
}

\author{
Şükrü Özen and Ümit Berkman
}

Şükrü Özen

Başkent University,

Ankara, Turkey

Ümit Berkman

Bilkent University,

Ankara, Turkey
Organization

Studies

28(06): 825-851

ISSN 0170-8406

Copyright (C) 2007

SAGE Publications

(Los Angeles,

London, New Delhi

and Singapore)

\section{Abstract}

Drawing on the discursive and translative perspectives, we examine the discourse produced by an elite group of corporate executives to legitimate TQM (total quality management) at the national level in Turkey. The findings indicate that the legitimating agencies largely used ethos justifications exploiting the macro-cultural discourses prevalent in the Turkish context. As such, they reconstructed TQM as a blueprint embracing solutions to the problems at societal, organizational, and individual levels. Based on the findings, we propose that reconstruction of imported practices in recipient contexts is more likely to involve ethos justification when compared to the construction of the original rhetoric because of the nature of cross-national translation. The strategy of ethos justification is even more likely when legitimating actors also strive to legitimate themselves as a social group, and/or to promote the practice to the public. Furthermore, the recipient discourse will be less coherent if legitimating actors have less formal authority and loose structure, and the target audiences have diverse values and expectations. We suggest that, under these circumstances, the reconstruction of the imported practices is more likely to produce fashions than institutions, a limited diffusion of the practice in contrast to the intentions of legitimating actors.

Keywords: cross-national reconstruction of managerial practices, new institutional theory, TQM, legitimation, translation, discourse, rhetoric

The recent increase in the cross-national transfer of managerial practices has raised the issue of the reconstruction of managerial practices at the crossnational level (Alvarez 1998; Sahlin-Andersson and Engwall 2002). Studies with institutionalist flavor mainly emphasize the effects of country-specific institutional factors on the diffusion of the transferred practices (Aguilera and Cuervo-Cazurra 2004; Casper and Hancke 1999; Cole 1989; Gooderham et al. 1999; Guillén 1994; Guler et al. 2002). As such, they largely concentrate on the diffusion process rather than the reconstruction process (Sturdy 2004). On the other hand, translative studies yield a more insightful perspective describing how managerial practices are 'translated' in the recipient contexts (Czarniawska and Joerges 1996; Frenkel 2005; Morris and Lancaster 2006). However, they do not provide specific propositions to explain the contingencies of cross-national reconstruction process. Finally, discursive studies explain the constitution of managerial discourses by taking into account the contingencies of text, agency, and context, but they do 
not specifically consider the reconstruction of discourses traveling across nations (Abrahamson and Fairchild 1999; Green 2004; Heracleous and Barrett 2001; Phillips et al. 2004).

In this study, we examine the reconstruction of TQM (total quality management) at the national level in Turkey with the aim of elaborating the issue of crossnational reconstruction of managerial practices. We suggest that, when used together, the discursive and translative perspectives offer a good starting point for the analysis of the reconstruction of imported managerial practices in the recipient context. However, they should be further improved to account for the factors constituting the discourse of the transferred practice in the recipient context, such as the characterictics of legitimating actors, the macro-cultural discourses prevailing in the recipient context, and the discourse of the imported practice itself. We particularly aim at developing propositions that concern the influences of these factors by using the instrumental case study approach (Stake 2000). In studying the case, we specifically analyze the texts produced by the actors to legitimate TQM at the national level in Turkey.

We begin by constructing a conceptual framework articulating the insights from discursive and translative perspectives. Next, we examine the case by focusing on the rhetorical themes and strategies that were employed by legitimating actors in constituting the TQM discourse in Turkey. Then, we compare the Turkish TQM discourse with the US discourse to illustrate how and to what extent the recipient discourse differed from the source discourse. Drawing on the implications of the case, we also suggest some propositions that can contribute to the understanding of cross-national reconstruction process. We conclude by proposing outlets for future research.

\section{Cross-national Reconstruction of Managerial Practices}

Drawing particularly on Czarniawska and Joerges (1996) and Phillips et al. (2004), we develop a conceptual framework, depicted in Figure 1, in order to explain how a managerial practice imported from a source country is reconstructed in the recipient context. In the framework, we suggest that a transferred management practice is reconstructed through a process in which competing or collaborating agents attempt to translate the practice (source discourse) by producing texts (recipient rhetoric) on which the legitimacy and authority structure of actors, the rhetoric inherent in the source discourse, and the macro-cultural discourses within the recipient context are influential. The recipient rhetoric, then, embeds in the recipient discourse that constitutes the reconstructed practice as either a fashion or an institution in the recipient context. The reconstructed practice might become a source discourse as it is transferred to a recipient country. Here, the term text refers to any kind of symbolic expression that may be in various forms such as writtens texts, spoken words, pictures, symbols, artifacts, and so on (Phillips et al. 2004). Rhetoric is defined as a type of spoken or written text used to persuade audiences by justifying a managerial practice (Green 2004). Finally, discourse refers to 'a system of statements which constructs an object' (Phillips et al. 2004: 636), here a managerial practice. 
Figure 1.

The Cross-national

Translation of

Managerial

Practices

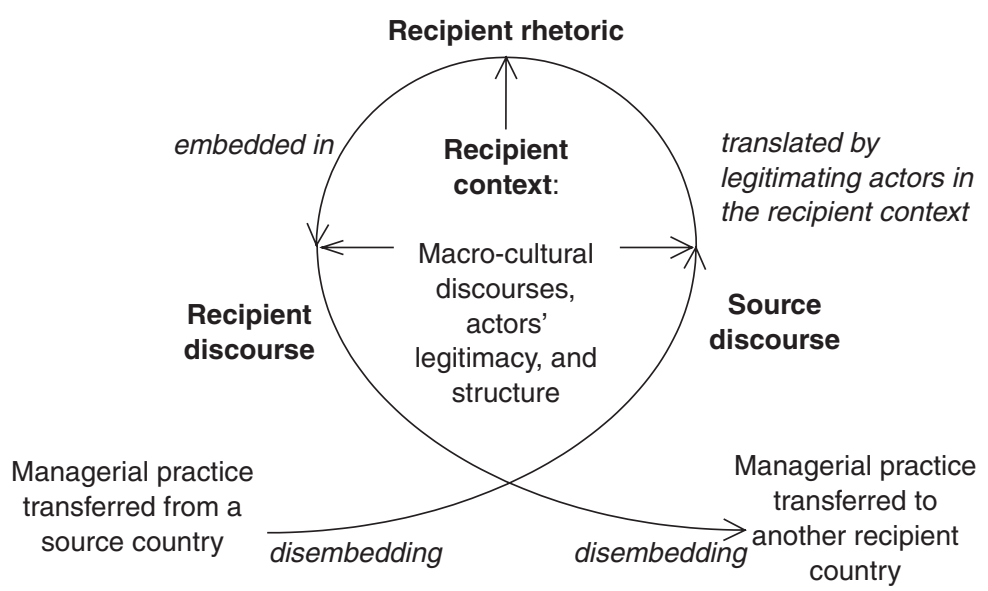

The source country in the framework represents the country from which a recipient country transfers a managerial practice, which may have been invented in the source country or transferred from another source country. In its source country, a managerial practice, whether it is a fashion or an institution (for difference, see Zeitz et al. 1999), is 'theorized' by both fashion setters and practitioners through a range of rhetorical texts that constitute the discourse of that practice (Abrahamson 1996; Abrahamson and Fairchild 1999; Greenwood et al. 2002; Strang and Meyer 1994). TQM, for instance, was first objectified by such publications as Deming (1986), Juran (1989), and Ishikawa (1985) inspired by Japanese quality practices. In its initial theorization, TQM was largely legitimated by rationalist and nationalist justifications stressing that it would lead to efficiency gains by improving organizational systems and processes, and therefore it would help the US overcome its 'productivity crisis' (Abrahamson 1997; Barley and Kunda 1992). However, diffusion of TQM among organizations in the US was accompanied by an emergent normative rhetoric involving employee involvement and empowerment (Abrahamson 1997; Barley and Kunda 1992; Hackman and Wageman 1995; Zbaracki 1998). Thus, a managerial practice such as TQM is transferred to another context as 'a source discourse' with its inherent rhetoric to be translated by agents in the recipient context (Czarniawska and Joerges 1996). By the term 'source' discourse, we do not mean that a managerial practice necessarily has an 'ideal', 'true' or 'original' discourse that should be kept in cross-national translation. The recipient discourse of a practice may well differ from the source discourse since the transferred practice is largely reconstructed according to the contingencies in the recipient context, and therefore this never implies that the recipient discourse is a 'distorted' version of the 'correct' source discourse.

The transfer of managerial practices may be triggered by changes in economic, social, and political realms (Abrahamson 1996; Greenwood et al. 2002; Greenwood and Hinings 1996), and/or by internal contradictions in the recipient context (Seo and Creed 2002). These contextual factors may also lead to the emergence of new actors who are usually dissatisfied with the 
existing institutional order (Greenwood et al. 2002; Seo and Creed 2002). These actors, called 'institutional entrepreneurs' (DiMaggio 1988), may attempt to exploit the imported practice in order to change the existing institutions, and thereby to realize their interests (Greenwood and Hinings 1996: 1036). Hence, they play a crucial role in delegitimizing (Greenwood et al. 2002) the existing institutions by specifying 'the organizational problem' (for instance, performance gap), and justifying the imported practice as 'the solution' (Abrahamson and Fairchild 1999). As such, these actors generate texts translating and re-embedding (Czarniawska and Joerges 1996) the imported practice in the recipient context by producing recipient rhetoric (Phillips et al. 2004). In this way, they attempt to legitimate the imported practice as well as themselves as a social group.

The recipient rhetoric produces pragmatic and moral legitimacy (Suchman 1995) for the imported practice. Green (2004) relates pragmatic and moral legitimacy with Aristotle's three classical forms of rhetorical justifications: pathos, logos, and ethos. These are the rhetorical strategies followed by legitimating agencies (or 'protagonists') in order to make their general viewpoints more convincing (Mueller et al. 2004). Pathos rhetoric appeals to the emotions of individuals (e.g., fear, greed, etc), logos rhetoric to the desire for efficient/effective action, and ethos rhetoric to socially accepted norms and mores. Green (2004) suggests that pathos and logos justifications are effective in producing pragmatic legitimacy that is based on audience self-interest whereas ethos justifications produce moral legitimacy based on normative approval (Suchman 1995). In the translation of the imported practice, ethos justifications are frequently used by the legitimating actors with references to master ideas or 'macrocultural discourses' which are 'the broad discourses and associated sets of institutions that extend beyond the boundaries of any institutional field and are widely understood and broadly accepted in a society' (Lawrence and Phillips 2004: 691). The power of macro-cultural discourses resides in their taken-forgranted explanatory power and obviousness (Czarniawska and Joerges 1996: 37). For example, Frenkel (2005) found that the scientific management and human resources models imported from the US to the Israeli context were reinterpreted by various actors such as the Israeli state, private employers, and a labor union within the framework of the macro-cultural discourses prevalent in the Israeli context such as nationalism and state building.

The translated texts, however, do not always smoothly embed in a recipient discourse (Phillips et al. 2004). It is more likely for a recipient rhetoric to embed in a recipient discourse if it is produced by powerful actors, conforms to appropriate genres, and/or draws on other texts (p. 643). The recipient discourse, on the other hand, is more likely to produce an institution if it is coherent and supported by broader discourses, and is not highly contested by competing discourses (p. 645). Thus, this means that the reconstruction process of the imported practice may produce either an institution, or a fashion, or a total failure.

Although this framework presents us a general outline of reconstruction process, it does not explain how the characterictics of legitimating actors, the context, and the imported practice interrelatedly shape the recipient rhetoric. It fails to specify under which conditions the rhetorical strategies of ethos, logos, 
and pathos are more likely to be used in the recipient context, and what the implications of different strategies would be in terms of the constitution of recipient discourse. For instance, it does not enable us to understand the extent to which the legitimacy and authority structure of legitimating actors influence their rhetorical strategies. It also does not consider which rhetorical strategies are more likely to reconstruct the imported practice as an institution or a fashion. The case of TQM reconstruction in Turkey is expected to provide insights to elaborate on these issues.

\section{TQM in the Turkish Context, and Legitimating Actors}

TQM became a widespread managerial practice (or 'fad') in many countries during the 1980s and 1990s (Carson et al. 2000). It was originally developed in Japanese companies as 'total quality control' with the help of US experts after World War II. However, it did not gain wide recognition until it was transferred to the US, and was reconstructed there mainly by Deming (1986), Juran (1989), and Ishikawa (1985). During this process its name evolved into 'total quality management' (Xu 1999).

In Turkey, widespread diffusion of TQM took place during the 1990s after the formation of an institutional environment promoting adoption of TQM at the national level. The Turkish Industrialists' and Businessmen's Association (TUSIAD), representing large entrepreneurs at the center of the Turkish business environment since the early 1970 s, initiated the quality movement at the beginning of the 1990s. TUSIAD mobilized top executives of the biggest business groups to establish a quality advocacy NGO, KALDER ('quality organization') with the aim of diffusing the quality philosophy among organizations and the public in general. Since then, KALDER members, who are largely corporate managers and professionals, have worked in close coordination with TUSIAD in promoting the adoption of TQM through various mechanisms such as training programs, publications, congresses, and quality prizes.

TUSIAD and KALDER have emerged as legitimating agencies from the context where state-business relationships have changed in response to the macroeconomic changes (i.e. liberalization) experienced since the early 1980s. The big business groups around TUSIAD had generally been created by the state during the early phase of the industrialization process (Buğra 1994). Due to their dependence on the state, and uncertainties in the political and economic spheres that have constituted an impediment to the development of a self-confident bourgeoisie, the big entrepreneurs have had a fragile social legitimacy (Buğra 1994). In her study on the discourse of the big entrepreneurs, Buğra (1994) found that they have invariably accentuated state support as the main source of their fortune without placing much emphasis on their entrepreneurship. Accordingly, they have produced a legitimating discourse presenting themselves as servants of the nation, receiving resources from the state, and converting them to productive investments. Their legitimating discourse has always involved loyalty to the state, and their contributions to the modernization goal set by the founder of the Turkish Republic, Mustafa Kemal Atatürk, 'to reach the level of modern civilization' (Heper 1985). 
This discourse of the TUSIAD circle has in fact been embedded in the macro-cultural discourses in Turkey, which has largely been manifested within the Kemalist ideology. This ideology on which the Turkish Republic was built has become such a dominant 'institution' in social and political life that various social groups and actors have attempted to acquire and enhance their social and political legitimacy by demonstrating their conformity to it (Heper 1985). The ideology has six main principles: republicanism, secularism, nationalism, populism, étatism, and reformism. Shaped by these principles, the Turkish business environment has been characterized by the state-dependent business system (Gökşen and Üsdiken 2001) constituted within the statist-society polity (Jepperson and Meyer 1991). In this polity, there has been a patrimonial state tradition that has given primacy to the collectivity and 'the general public interest' (i.e. the state and state-formulated goals), but not to 'individual or specific social groups' (Özen 1993: 26-27). Here, economic development has always been one of the unquestionable aims of the Turkish Republic, and therefore, not an area of struggle but 'a national endeavor, a common goal which it would be unpatriotic to question' (Eralp 1990: 253). On the other hand, nationalism involves 'state-building nationalism' (Hechter 2000) which is based on Turkish identity and culture, transforming the multicultural society inherited from the Ottoman Empire to a culturally homogeneous one. Thus, 'congruence with the Turkish culture and identity' has been frequently invoked as a (de)legitimating strategy in the Turkish polity.

Due to the protectionist policies and clientelist relations between big business and the state elites, TUSIAD gradually became a powerful interest association reflecting and effectively legitimating the interests of big businesses during the 1970s (Gülfidan 1993). In addition to this, backed by the liberalization policies followed in Turkey since the early 1980s, it has also ascribed to itself a change agent role that would contribute to both economic and political liberalization of the country in line with its demand for full membership of the European Union: through this role, it has aimed at transforming the state and society in line with the European model, and thereby improving its own political power and legitimacy (Buğra 1998; Gülfidan 1993). Thus, TUSIAD has evolved from a mere legitimacy-seeking, identity association to a change agent. Throughout this process, its discourse has been articulated with the neo-liberal and global competition discourses (Ehrensal 1995) while keeping its national developmentalist tone.

It is as a part of this 'institutional project' that TUSIAD initiated the quality movement at the national level. Through this sub-project, TUSIAD mobilized corporate executives and led them to establish KALDER. In fact, there has always been a trust problem between professional managers and shareholder families in Turkish companies, sometimes characterized as a 'love-hate' relationship (Buğra 1994). The big business groups in Turkey have been centrally controlled by the owning families, leaving little room for discretion to professional managers: they have usually played a stewardship role in the big holding companies (Buğra 1994; Gökşen and Üsdiken 2001). Hence, Turkish professional managers have not gained a social group identity independent of their bosses (Buğra 1994). However, the liberalization policies that have somehow 
increased domestic competition in terms of quality, variety, and productivity seem to have provided professionals with an opportunity to enhance their legitimacy, and build a group identity.

Professionals, as 'emerging actors' (Greenwood et al. 2002; Seo and Creed 2002), have been keen to capitalize on this opportunity. By 1998 about 22,000 people had attended training programs covering a wide range of topics from particular quality control techniques to total quality philosophy (KALDER 1998). The same year KALDER launched an extensive project entitled 'National Quality Movement' in order to diffuse TQM throughout the country. KALDER also publishes a monthly periodical, Önce Kalite ('quality first'), where the experiences of various TQM-adopting companies are reported. In addition, the organization has hosted national quality congresses, and has awarded quality prizes in collaboration with TUSIAD since 1993.

\section{Recipient Rhetoric and Discourse}

\section{Sample and Method}

In this section, we study the KALDER circle's literature by the text analysis method (Silverman 2000) in order to ascertain its rhetorical themes and strategies. In data collection, we first identified the corpus of texts, and then selected the units of analysis of the texts (Ryan and Bernard 2000: 780). Since we were interested in how the actors legitimated TQM to the public at the national level, we identified, as the corpus, those texts on TQM produced by key figures in the 'quality movement' between 1994 and 1998 which were openly accessible to the public and other interested parties. The first author collected and selected the documents consistent with the above criteria. The corpus of the texts thus consisted of: interviews with key figures of the quality movement that were published in the journal Önce Kalite or in the national press; speeches by key figures at Turkish national quality congresses; a book on TQM published by one of the pioneers of the quality movement in Turkey, İbrahim Kavrakoğlu; a handout on TQM used in KALDER's training seminars provided to the public; and the TQM introductory page on KALDER's website (www.kalder.org.tr). The individuals whose texts were selected were pioneering members of the quality movement, top executives of award-winning (EFQM and TUSIAD/KALDER prizes) holding companies, and members or higher officers of KALDER. Hence, this sample represents how KALDER with its top volunteers legitimated TQM at the national level. (For a list of key figures and the documents used in the study, see Appendix.)

In order to select the unit of analysis of the texts, the two authors independently read the collected documents to highlight all 'text segments' (Greenwood et al. 2002) in which the speaker or author presented, described, or referred to TQM to persuade the audience to adopt it. We also paid attention to the selection of those texts that constituted a whole in itself, i.e. 'thematic units' not overlapping with other units of analysis of texts (Ryan and Bernard 2000: 780). Thus, we selected sentences, paragraphs, and sometimes, a complete block of paragraphs as the text segments. Then we compared the segments selected, and tried 
to convince each other that the selected segment satisfied the selection criteria above. The segments on which the authors failed to agree were dropped. The resultant agreement rate between the authors was found to be acceptable, $85.2 \%$ (Miles and Huberman 1984), and the final sample consisted of 25 text segments, listed in Table 1.

In order to discover the rhetorical themes and strategies, both authors and a senior doctoral student in management and organization theory who was familiar with rhetorical theory independently coded the selected text segments. The rhetorical theme refers to the main argument emphasized by a text segment to justify TQM adoption. The rhetorical strategy, on the other hand, refers to the forms of persuasive appeals that the main argument is intended to produce. We first coded the rhetorical themes by using an 'inductive coding' method (Ryan and Bernard 2000: 781). With some differences in wording, the agreement rate was $93.3 \%$. We resolved coding differences by discussion and mutual agreement, and reached the themes presented in Table 1.

Then, we independently determined the rhetorical strategies by using the pathos, logos, and ethos justifications as the coding scheme. As defined by Green (2004: 659-660), pathos justifications, which build pragmatic legitimacy, appeal to emotions of individuals (e.g. fear, greed, and so on) and to an audience's self-interest. Logos justifications, on the other hand, 'tend to elicit methodical calculation of means and ends to achieve efficiency and effectiveness' and, like pathos, help build pragmatic legitimacy (p. 659). Finally, ethos justifications affect moral or ethical sensibilities by appealing to socially accepted norms and mores. Rather than individual concerns and interests, ethos appeals focus on social and collective interests that produce moral legitimacy. In coding, we focused on the latent content of the segments to capture the 'deep structure' or implicit categories of meaning behind the words and sentences used (Suddaby and Greenwood 2005). In this regard, the themes we coded at the previous stage helped us determine the intended persuasive appeals since we noticed that certain themes were associated with certain rhetorical strategies, as will be detailed in the following section. Furthermore, we also noticed more than one rhetorical strategy embedded in a text segment in a nested fashion, and therefore we decided to use more than one category for such segments. The final agreement rate was $85.3 \%$. The raters then discussed discrepancies and made the appropriate changes in the coded texts, and reached the rhetorical strategies reported in Table 1.

\section{Rhetorical Themes and Strategies in Recipient Context}

The findings presented in Table 1 show that 15 different themes are stressed in the text segments, varying from global competition and national development to efficiency and profitability. Among the themes, national development is the most stressed theme (10 times); then each of the themes global competition, Japanese model, reformism, and cultural fit is stressed four times. To a lesser degree, national pride, and individual growth and peace are emphasized three times, and modernism and social welfare are stressed twice. Finally, themes related to 'rationality' such as efficiency, profitability, overall effectiveness, 
Table 1. The Rhetorical Strategies and Themes in the Reconstruction of TQM in Turkey

\begin{tabular}{l} 
No. Text segments \\
\hline 1 \\
Why TQM? It is just because of competition. The fast growing competition, \\
technological developments, communication and transportation systems, spread \\
of free-market economic system, lowering protectionism in international trade \\
all have brought a global market. There is now not only domestic but also \\
world competition. The number of companies who want to take their shares \\
from the world market has been increasing. To survive in this race, to adapt to \\
competition have forced companies to find new approaches. TQM and \\
efficiency programs are the consequences of these searches (Sidi 1994).
\end{tabular}

In the second half of the 20th century, a new era in industry and

Global commerce began. We can describe the main characteristics of this era as globalization and destructive competition... When we examine organizations Competition

Themes
Global
Competition+
Efficiency

Rhetoric

that are successful in the new environment, we see that their common characteristic is to adopt Total Quality Management philosophy and its approach (Kavrakoğlu 1998:9).

National Quality Movement is the result of a requirement. Nations who do not have competitive power in the globalizing world will not be able to survive, and to become a strong nation in international competition depends on quality practices...The whole country have to understand the importance of these quality practices, and this can be possible by a holistic movement (Kilitçioğlu 1998: 12-14)

As known, there has been a supply surplus in most of the industrialized countries... Manufacturers who tried to attract customers competed mercilessly with each other to provide high quality, broad product variety, and service. Within a short period between 1945 and 1975, Japan jumped into the first league, and entered 1990s as the number one in many sectors. But, as well known, there is a new method of industrial organizing behind Japan's magnificent success, and in the core of this method there is 'Total Quality' approach' (Kavrakoğlu 1998:12)

We, as a nation, have to accomplish total quality in every field, and we have no other chance to reach the level of developed countries and compete with them in the twenty-first century. (Güven 1994)

Many things will change in Turkey. First, traditional structures will change. These changes are still inherent in the goals of the National Quality Movement. We aim at diffusing a new practice nationwide, and when this is achieved, in fact absolutely achieved, we will see that our nation will change rapidly. ... TQM is a scientific practice, and an important accumulation of experiences has been achieved in this subject in our country. The diffusion of this accumulation and the changes within many organizations will create extremely positive influences (Kilitçioğlu 1998)

$7 \quad$ 'Stating that this movement started in the 75th anniversary of the Republic overlap with Atatürk's vision of modern civilization, Argüden emphasizes that higher goals have to be targeted in the National Quality Movement. Noting the possession of national capacity required for reaching these goals, Argüden states: 'The National Quality Movement should be evaluated as the way to reach the national goal, beyond all individual and organizational interests, for the future of Turkey which deserves a high quality of life.' (Argüden 1998:13)

We have to apply Quality Revolution to societal structure to reach and exceed the modern civilization level. The systems we have to understand, improve, and renovate are societal systems (Gökçe 1997:22)

Global

Competition+

National

Development

Global

Competition+

Japanese

Model+

Method

National

Development

Pathos+

Ethos

National

Pathos+ Ethos+

Development

and Reformism+

Scientific

Practice

Logos

Pathos+Ethos+

Logos

National

Ethos

Development+

Reformism

National

Ethos

Development+

Reformism

National

Ethos

Development+ 
Table 1. (continued)

\begin{tabular}{llll}
\hline No. & Text segments & Themes & Rhetoric \\
\hline
\end{tabular}

this change process, it did not only internalize best practices, but also constituted itself as world standards and benchmark for the independence of other poor nations. I am sure that in the synergy of Modern Total Quality Management we will find the opportunity of enhancing societal life quality by approaching systematically our needs and developing our capacity accordingly (Gökçe 1997: 22)

10 Turkish industry that has been underdeveloped in quality systems can create a new Japan with its leap in quality. The only requirement is to learn the components of total quality in the right way, and that management has to accomplish its fundamental responsibility

(Kavrakoğlu 1998: 69)

11 As known, Japan increased its exports 17 times within the period 1967-1987. It is just enough for Turkey that increased its export 4.2 times between 1980 and 1991 to repeat again its performance in the last decade to equal this unique record. Here is the most important candidate to realize this performance:

TQM (Kavrakoğlu 1998: 72)

12 I evaluate that TQM is the management mentality of our century that will prove a important tool, to increase our country's competitive power, our people's productivity, and in turn individual happiness. What motivates me most in my life is to be able to make good things. Therefore, I took this mission because I thought that the spread of this philosophy would be beneficial (Argüden 1998)

13 The night BRISA and NETAS were awarded was in fact the night of great honor for Turkey. For us the awards mean a great contribution to Turkish economy. Because this is not only the achievement of BRISA and NETAS, but also the achievement of Turkey (Argun 1998)

14 In today's world, the modern management philosophy, which ... has extensively been known as Total Quality Management, has rapidly diffused in manufacturing and service industries. Its implementation fails usually because of shallow approaches. However, the companies that foresee or experience competition have inevitably adopted TQM eventually (Güven 1994)

15 As known, Total Quality Management (TQM) is not only a technique related to product and service quality but a modern management approach of today (Kavrakoğlu 1998:9)

In Turkish culture, there are collective decision-making mechanisms. For instance, in the past there were 'divans'. When you look at Turkish culture, you will see a democratic structure where there is no gender discrimination. Today, we have been successful in a continuously and orderly manner in the implementation TQM in Europe, which we had never achieved in another field. ... There are excellent examples in Turkey in the application of TQM. This is the indication that TQM fits Turkish culture (Argüden 1998)
Reformism

National Ethos

Development+

Japanese

Model

National

Ethos

Development+

Japanese

Model

National

Ethos

Development+

National

Pride

National Pride Ethos

Modernism

Ethos+

Pathos

Modernism+

Ethos+

Technique

Logos

Cultural

Ethos

Fit+National

Pride

Cultural Fit

Ethos principles. These principles are very coherent with Turkish character. It is very consistent with the basic characteristics like a Turk's modesty. One of the reasons for our European success may be the motto 'mü?teri velinimetimizdir' (customers are always right). This motto has been for centuries written on the wall of local grocery stores; this has become a part of our culture. This is an 
Table 1. (continued)

\begin{tabular}{llll}
\hline No. & Text segments & Themes & Rhetoric
\end{tabular}

indicator of mentality in which the customer is above everything. It is clear that the genuine Turkish culture will support TQM applications (Argun 1997)

Total quality and the search for excellence at work should not be limited to companies; it should be furthered beyond companies. We have observed this in the personal life of our employees. It can be applied to the family life. We observed that family members participate in the decision-making in family, although our society is a patriarchal one. We are hearing that our employees start to consult with their spouse and children. Thus, I believe that TQM is a lifestyle that can and should be adopted by every sector of society (Piker 1997)

According to KAIZEN philosophy, our working life, social life and family life have to be improved continuously. .....In the Islamic philosophy, Mohammed the Prophet emphasized the same thing with his hadith 'those whose subsequent two days are the same are lost' (KALDER 1999)

...We have many things to do to increase the quality in society and to enhance the order of human relations. We have to be aware of this and have to take the responsibility. TQM provides this. I mean, it is useful in terms of developing democracy. It helps us perceive the problems as our problems' not those of others. What does TQM say to solve these problems? It says 'work!' Total Quality is a philosophy where people take responsibility instead of waiting for solutions from somebody at the top (Argüden 1998)

\section{Cultural Fit Ethos}

National Ethos+Pathos

Development+ Individual Growth and Peace

TQM attempts to determine the happiness of the people according to their position in the work processes and it refers to these people in different positions as stakeholders. The target of TQM is to maximize the happiness of these people in balance (Argun 1997)

\section{Individual \\ Growth and Peace+Social Welfare}

Social Welfare

Ethos
Ethos+Pathos

...TQM is not only necessary for manufacturing and service organizations but also for the future of social welfare. Thus, it has to be diffused nationwide (Argun 1997)

When you look at organizations applying TQM, you will see that the employees are happy there. Our goal is also to create a workforce proud of working in our organization (Argun 1997)

24 TQM, which is the basic factor in the success of Japanese companies and many worldwide corporations, is defined as achieving profitability by satisfying customers and society through continuously improving the activities in an organization with the participation of all employees in the organization...

(www.kalder.org.tr)

$\begin{array}{ll}\begin{array}{l}\text { Individual } \\ \text { Growth and } \\ \text { Peace }\end{array} & \text { Pathos } \\ \text { Japanese } & \text { Ethos+Logos } \\ \text { Model+ } & \\ \text { Profitability } & \end{array}$

Organizational Logos+Pathos Effectiveness
The Basic Components of TQM: Customer-orientedness... Cooperation with Suppliers...Employee Growth and Participation Processes and Data-Driven Management...Continuous Improvement and Creativity...Leadership and Goal Coherence (www.kalder.org.tr)

method, technique, and scientific practice are mentioned only once. These findings indicate that the rhetorical themes stressed in the TQM discourse in Turkey draw largely on those themes inherent within the macro-cultural discourses prevalent in the Turkish context, such as the Kemalist ideology and the historical Turkish sympathy toward Japan (i.e. national development, reformism, cultural fit, national pride, and Japanese model). They also seem to be inspired by the universal discourses such as global competition, modernism, social welfare, 
and to a lesser degree, by the rational and normative themes inherent within the source rhetoric of TQM, such as individual growth, efficiency, profitability, and overall effectiveness.

These themes can inform us about the rhetorical strategies employed in the text segments (i.e. certain themes are associated with certain rhetorical strategies). For instance, the theme global competition is associated with pathos rhetoric since it appeals to emotions of fear of being destroyed by global competition, and failing to adapt to a 'natural' global change. Furthermore, the theme individual growth and peace, and the 'normative' side of organizational effectiveness (i.e. employee growth and participation, leadership, and goal coherence) are associated with pathos rhetoric due to their appeal to the sense of individual 'happiness' and 'self-actualization'. On the other hand, themes such as profitability, efficiency, method, technique, scientific practice and the 'rational' part of organizational effectiveness (customer orientation, cooperation with suppliers, processes and data-driven management, continuous improvement and creativity) are used to appeal to 'rationality' (i.e. logos rhetoric). It is significant to note that these themes have also been embedded in the source pathos and logos rhetorics of TQM (see Green 2004): a pathos rhetoric appealing to the fear of being outperformed by Japanese and German companies, and the sense of self-actualization through employee involvement and empowerment on the one hand, a logos rhetoric appealing to productivity, efficiency, and quality improvement through improving organizational systems and processes on the other (see Abrahamson 1997; Barley and Kunda 1992; Green 2004; Hackman and Wageman 1995; Zbaracki 1998). The themes with strong referrences to Kemalist ideology and the historical Turkish sympathy toward Japan are used in the ethos rhetorical strategies since TQM is legitimated here by resting on the strong moral legitimacy of the macro-cultural discourses which are widely understood and broadly accepted in Turkish society. The themes of modernism and social welfare are also related to the ethos strategy because TQM is legitimated with universally taken-for-granted narratives of modernism and social welfare. Thus, following Green (2004), we can say that in order to legitimate TQM in the moral sense, the legitimating actors draw largely on the master ideas in the Turkish and global contexts whereas they employ the source TQM rhetoric in order to build pragmatic legitimacy.

As for the rhetorical strategies followed in the text segments, the findings show that the KALDER circle attempted to translate, or legitimate, TQM by depending largely on ethos appeals connected with macro-cultural discourses in the Turkish context. Out of 25 text segments studied, 12 (48\%) are purely ethos justifications, and two (8\%) purely pathos justifications: none of the text segments is purely logos. There are also five combinations of ethos and pathos justifications (20\%), two ethos-logos (8\%), two pathos-logos (8\%), and finally, two ethos-pathos-logos combinations $(8 \%)$. It is noteworthy that, except for two pathos-logos combinations, ethos justification appears in all text segments, alone or together with other rhetorical strategies: out of a total of 38 hits, ethos strategy receives 21 hits (55\%), pathos strategy 11 hits (29\%), and logos strategy 6 hits (16\%).

KALDER members amply employ nationalistic appeals in the ethos justifications, sometimes together with other themes such as the Japanese model and 
modernism. The theme of national development, which is frequently accentuated in the texts (text segments 3, 5 through 12, and 20), can be seen as the articulation of TQM rhetoric with the discourse of business people historically constituted in the Turkish context (i.e. to legitimate themselves and their actions by emphasizing their contributions to state-formulated economic and social development or to the modernization goals set by Atatürk, the founder ('beyond all individual and organizational interests'; text segment 7). In this way, the legitimating actors enhance the moral legitimacy of TQM by presenting it as the way to realize the national dictum of 'to reach the level of modern civilization' (for instance, text segments 7, 8, and 9), which has been the core master idea of Kemalism in Turkey. By doing so, they seem to conform not only to the nationalist ideal of Kemalist ideology, but also to its reformism principle by emphasizing the urgent need for nationwide revolutionary change (text segments 6, 7, and 8). They also build moral legitimacy by stressing the potential gains from TQM adoption (i.e. positive social and economic changes) and the current successes of TQM adoption that enhance the image of Turkey (i.e. national pride at the winning of EFQM prizes - see text segments $6,8,12,13$, and 16).

In the ethos rhetoric, 'Japanese connection' frequently appears (text segments 4, 10, 11, and 24). TQM is evaluated as the main factor behind 'the Japanese miracle', and 'Japan' is presented as a role model for national and organizational success through TQM. As is widely known, there has been considerable sympathy (sometimes to the extent of admiration) toward Japan among Turkish people because of their historical relations, and similarities in terms of relations with the western world (e.g. having a common enemy, Russia, at the turn of the 19th century) (see Esenbel and Chiharu 2003). Therefore, the use of Japan as a role model in TQM rhetoric appeals to the attitudes of Turkish society, and furthers the moral legitimacy of TQM. On the other hand, the ethos rhetoric is also coupled with the meta-narrative of modernism. In the texts (for instance, text segments 9, 14, and 15) TQM is presented as 'the modern' management philosophy. Given the worldwide normative, even 'taken-for-granted', attachment to modernity (Meyer and Rowan 1977), this theme is expected to increase the moral legitimacy of TQM. Furthermore, taking into account the fact that the Kemalist project has been known as 'a typical modernization project', this theme is also said to be congruent with the macro-cultural discourse.

In the ethos justification, TQM is also legitimized by emphasizing its congruence to the cultural and religious characteristics of Turkish society (see text segments 16 through 19). In so doing, the texts claim that TQM is congruent with the historical collective decision-making mechanisms, egalitarian culture, value given to customer, and family structure of Turkish society. Beyond that, TQM is also presented as a method for improving the health of family life when implemented at home (text segment 18). The actors also legitimate TQM by referring to its fit with Islam, the dominant religion in Turkey (text segment 19). They creatively find congruence between continuous improvement (kaizen) and Islam by referring to one of the hadiths of Muhammad the Prophet. The rationale behind the 'cultural fit' theme seems to legitimate TQM in the moral sense by indicating its consistency with socially accepted norms, and with routines in the Turkish context. Moreover, 
emphasizing TQM's congruence with Turkish culture implies its fit with the nationalist principle of Kemalism, which is sensitive to preserving Turkish culture and identity. Finally, based on the social welfare theme, TQM is legitimated by arguing that it enhances participation and democracy at societal level (text segment 20). Furthermore, it is claimed that it will improve social welfare by maximizing the interests of different social groups (text segments 21 and 22). These themes apparently legitimise TQM by depending on socially valued models at societal level (i.e. a consensual and harmonious social order).

In the pathos justifications, the emotion of fear is appealed to by emphasizing the threat of global competition. TQM is presented as 'the natural consequence of globalization', and 'the only way for both organizations and nations to survive in the globalized world system' (text segments 1, 2, 3, and 4). The globalized world system is seen in the discourse as a system where nations and organizations are 'destructively' competing with each other and within which only those who adapt to these conditions can survive. The adoption of TQM is envisaged as the key strategy for adaptation and survival. Thus, the texts legitimate TQM by describing it as the only alternative: there is 'no other chance' (text segment 5). It is argued that globalization threatens both national survival and organizational survival. In so doing, the texts feed the fear with moral norms such as 'defending or saving one's own country against an external threat', that is, a pathos-ethos combination (text segment 3). Thus, TQM adoption is presented as the sole tool for national survival, development, and change in coping with the difficulties of globalism, which is an inevitable development (text segments 6 and 14). Furthermore, the pathos rhetoric appeals to the sense of missing something valuable by claiming, particularly in text segments 2,3 , and 14, that 'all successful companies and nations have already adopted TQM', implying 'if you have not yet adopted it, you are risking your chances of survival'. Finally, the pathos rhetoric also appeals to the emotions of happiness and self-actualization, particularly in the individual growth and peace theme. Throughout the text segments 20,21, 23, and 25, it is claimed that participation in TQM makes individual employees happier in the sense that they fulfill their responsibilities 'instead of waiting for solutions from the leaders'.

Although there does not exist any text segment representing purely logos justifications that attempt to elicit the TQM's 'methodical aspect to achieve efficiency and effectiveness', we have observed some statements underlying logos justifications which are scattered throughout various text segments such as 1, 4, 6, 15, 24, and 25. For instance, TQM is associated with 'efficiency programs' in text segment 1 , evaluated as 'a new method of industrial organizing' in text segment 4 , as 'a scientific practice' in text segment 6 , as 'a technique related to product and service quality' in text segment 15 , and as a tool 'to achieve profitability' in text segment 24. In text segment 25, the rational components of TQM are also emphasized. Through these phrases, TQM is presented as a rational means that should be used to achieve the desired ends such as productivity, quality, profitability, and so on. These themes, together with employee participation and empowerment, seem to be borrowed from the source TQM discourse. The principles, main components, and practices of TQM (Dean and Bowen 1994), and its possible outcomes (quality improvement, cost reduction, customer and employee satisfaction, and employee 
empowerment) are presented so that TQM is legitimated by its rational and normative rhetoric (Abrahamson 1997; Hackman and Wageman 1995).

\section{Source and Recipient TQM Discourses}

In this section, we compare the Turkish TQM discourse with its US counterpart in order to illustrate how and to what extent the recipient discourse of a practice might differ from the source discourse of that practice. We choose the US version of TQM as the source discourse because the US has been the main source of management knowledge including TQM for Turkey since the 1950s (Üsdiken 1996). Our comparison is not exhaustive, and is not based on primary data on the US context and the associated TQM discourse. Since the US TQM discourse has already been well articulated (see Abrahamson 1997; Abrahamson and Fairchild 1999; Barley and Kunda 1992; Cole 1995; Hackman and Wageman 1995; Zbaracki 1998; Academy of Management Review 1994), we draw mainly on the existing literature for our understanding.

As is shown in Table 2, the Turkish TQM discourse differs from the US discourse in several respects. The scope of the US discourse mainly concerns the effectiveness and health of the organization, as well as its relations with customers and suppliers, and the well-being of individual members of the organization (Hackman and Wageman 1997: 310). However, the scope of the reconstructed version of TQM is 'whole nation'. As presented in various text segments in Table 1 , TQM is reconstructed as a system or philosophy that has to be accomplished 'in every field' of society (text segment 5), applied 'to societal structure' or 'societal systems' (text segment 8), adopted by 'every sector of society as lifestyle' (text segment 18). As such, it is claimed, it enhances 'societal life quality' (text segment 9), improves 'democracy' (text segment 20), and 'social welfare' (text segment 22). With these representations, TQM, originally 'a management method' (Anderson et al. 1994), seems to be reconstructed by the legitimating agencies in Turkey as a system of social order or a political regime which will bring peace and welfare to the whole society. Thus, the scope of TQM has clearly expanded from the organizational to the societal level in the recipient discourse.

The problems perceived by the US TQM discourse are low productivity, low quality standards, and low employee commitment (Barley and Kunda 1992: 380). However, the problems focused on in the reconstruction are economic and social difficulties at the national level. We know that TQM is also seen as a way to move 'out of crisis' at the national level in the US (Deming 1986) with the simple reasoning that increased productivity at the organizational level would solve economic problems at the national level. As seen in the national development themes in Table 1, similar reasoning and themes can be found in the recipient discourse. However, what is different in the Turkish reconstruction is that TQM has also been presented as a system that can be applied directly at macro level to solve social and economic problems.

The orientation of the source TQM is both production and people in the sense that it focuses on the productivity of the organization and the well-being of employees (Abrahamson 1997; Carson et al. 2000). Although the reconstructed TQM also involves these dimensions, as seen in text segments 1, 4, 6, 
Table 2.

The Source and Recipient TQM Discourses

\begin{tabular}{lll}
\hline $\begin{array}{l}\text { Dimension } \\
\text { Scope }\end{array}$ & $\begin{array}{l}\text { The source (US) TQM } \\
\text { discourse }\end{array}$ & $\begin{array}{l}\text { The recipient (Turkish) } \\
\text { TQM discourse }\end{array}$ \\
Perceived problem & $\begin{array}{l}\text { Organization-wide } \\
\text { quality standards, } \\
\text { low employee commitment }\end{array}$ & $\begin{array}{l}\text { Nation-wide } \\
\text { in social and } \\
\text { economic domains }\end{array}$ \\
$\begin{array}{l}\text { Orientation } \\
\text { and people } \\
\text { The blame on } \\
\text { management }\end{array}$ & $\begin{array}{l}\text { Moderate } \\
\text { The role burdened } \\
\text { on management }\end{array}$ & $\begin{array}{l}\text { people } \\
\text { Absent }\end{array}$ \\
$\begin{array}{l}\text { The dominant } \\
\text { rhetorical strategy at } \\
\text { the introduction stage }\end{array}$ & $\begin{array}{l}\text { Creating and sustaining } \\
\text { an organizational system } \\
\text { that produces quality outcomes }\end{array}$ & $\begin{array}{l}\text { Change agent to contribute } \\
\text { to the social and economic } \\
\text { development of the country }\end{array}$ \\
\hline
\end{tabular}

$15,20,21,23,24$, and 25, its main emphasis is on 'the people' dimension, that is, the 'normative' side of TQM (Abrahamson 1997; Barley and Kunda 1992; Hackman and Wageman 1995; Zbaracki 1998). As seen in the texts, the alleged social gains of TQM such as participation, responsive behavior, individual happiness, democracy, lifestyle, stakeholder collaboration, social peace, and order are emphasized more than its technical gains.

In the source TQM discourse, there was a moderate blame on management for the performance problems experienced by US companies in the 1980s (Barley and Kunda 1992; Carson et al. 2000). However, in the reconstruction, we have seen almost no mention of 'the problem' and those who are responsible for the problem in Turkish companies. We have just seen, in passing, a phrase in text segment 10: 'Turkish industry that has been underdeveloped in quality systems'. However, this does not give any information about what was wrong with the existing production, human resources, and procurement systems in Turkish companies, and who was responsible for the problem. Thus, in the Turkish reconstruction we can say that the problem is defined not with respect to companies, but rather to macro systems (backwardness, national survival), and nobody is blamed. This implies that, in these circumstances, institutional entrepreneurs may well skip the delegitimation phase of the institutional change process (Greenwood et al. 2002). This may be due to one of the paradoxes of 'embedded agency' (Greenwood and Suddaby 2006) in the sense that any reference to organizational problems may mean admission of the actors' past incapability to the public, contradicting the high legitimacy concern of the same actors.

The source TQM discourse places on management the role of leadership to create constancy of purpose for improvement of products and services as well as a system that can produce quality outcomes (Spencer 1994: 447). The recipient TQM discourse seems to lay on managers a similar role, but going beyond the organization (i.e. toward the broader social and economic system). As seen in texts 
$6,8,12,13$, and 16, the actors emphasize their devotion and contributions to change and development in Turkey. The professional managers producing these texts not only reconstruct TQM but also construct themselves and their social identity. This identity, as constructed in the rhetoric, seems to be similar to the social change agent role that big businesses around TUSIAD have played since the early 1980s.

In its introduction stage in the US during the 1980s, TQM was legitimated largely by logos appeals, also supported by pathos and ethos justifications. Considering the founding texts constituting the ingredients of TQM in the US (Deming 1986; Juran 1989; Ishikawa 1985), we can say that TQM was introduced as a rational tool to solve the low productivity and quality problem in US companies through its customer-orientation, supplier-management, continuous improvement, and data-driven management components (Abrahamson 1997; Martin 1995; Spencer 1994). This logos rhetoric was also backed by pathos appeal that provoked a sense of fear connoted by global competition and the productivity crisis, and by ethos appeal emphasizing nationalistic fervor to overcome the crisis (Deming 1986). We have also learned from Hackman and Wageman (1995) that, in addition to its basic logos rhetoric, new pathos rhetoric emerged, emphasizing a sense of individual growth and self-actualization as the outcome of employee involvement and empowerment programs.

On the other hand, considering the sample in this study, TQM was introduced to Turkey for the most part through the ethos rhetoric involving themes varying from national development to cultural fit. We can say that with these characteristics, TQM in the recipient discourse becomes a blueprint through which a group of actors make sense of and interpret their world, explain uncertainties, find solutions to problems at all levels (individual, organizational, and societal), and constitute their identity. Due to TQM's 'not easily reproducible' nature, 'at least not in ways that remain loyal or similar to their initial form' (Hasselbladh and Kallinikos 2000: 711), the different reconstructions of TQM in different contexts are understandable (see Xu 1999). However, what is interesting in the Turkish case is that a management method, TQM (Anderson et al. 1994), becomes not only a blueprint for quality and productivity improvement in organizations but also a strategy for individual growth as well as social, political, and economic development at the national level. This seems to be similar to the case where protagonists follow rhetorical strategies, widening the argument to broader national and political issues in order to convince audiences of organizational change (Mueller et al. 2004: 88). However, as we will argue in the following section, widening the scope of TQM to the individual, social, political, and economic levels as in the Turkish case may produce an ambiguous discourse that may fail to convince others to adopt TQM, in contrast to the intentions of the legitimating agencies.

\section{Propositions for Cross-national Reconstruction Process}

The most striking finding of the study is that the legitimating actors in the Turkish case have attempted to justify TQM by using largely ethos justifications that are 
oriented to building moral legitimacy. Although this finding can be attributed to factors specific to the Turkish context, and cannot easily be generalized, it may provide some insights into the issue at hand. Drawing on Czarniawska and Joerges (1996), we can say that a foreign text can only be understood in relation to what the audiences in the recipient context already know. Thus, we think that in the legitimation of a foreign practice in the recipient context, references to the cultural norms and values that represent macro-cultural discourses embedded in that context are inevitable. This implies that when the managerial practice is imported to another context, its source rhetoric with pathos, logos, and ethos appeals becomes more ethos-oriented. If the argument that managerial practices involve inherently a rational progression (logos) rhetoric (Abrahamson 1996) is true, their transfer to another national context may not make their rhetoric less logos but more ethos. This resembles the case where a text (for example, an architectural or a clothing style) imported from another country (usually more developed) is presented to the recipient context (usually less developed) by referring not to its functionalities, since they are taken for granted, but to its symbolic and moral value (e.g. modernization, development, and so on). We think that if the recipient country takes the source country as a role model for developmental purposes, the legitimating actors, usually the elites identified with the developed source country (Alvarez 1998), would tend to emphasize the moral value of the practice they have transferred. This does not mean that the original pathos, logos, and ethos justifications are not used by legitimating actors in the recipient context: in the Turkish case they also drew on the source TQM discourse, although to a lesser degree. Moreover, the source discourse may be used extensively in the recipient context where the source and recipient countries are similar in terms of institutional and cultural characteristics (for instance, US and UK), or what is imported is a 'hard' technology rather than a 'soft' technology such as management knowledge (Alvarez 1998). However, here we focus on the transfer of a managerial practice (soft technology) from the US to Turkey, countries which were quite dissimilar in terms of cultural, political, and economic characteristics. This implies that even the logos type of rhetoric in which managerial practices by definition embed (Abrahamson 1996) may have to be translated in accordance with the meaning systems within the recipient country. Thus, the excessive use of ethos justification might not be totally attributable to the circumstances in the Turkish context, but to the nature of cross-national translation of managerial practices. In conclusion, we propose:

Proposition 1: When a managerial practice is imported to another national context, its recipient rhetoric will involve more ethos justifications than its source rhetoric.

The ethos flavor of recipient rhetoric may also depend on the characteristics of the legitimating actors who produce texts about the imported practice. Building on the suggestion of Phillips et al. (2004), we can say that the actors who need legitimacy enhancement generate more texts that constitute the recipient rhetoric. On the other hand, Phillips et al. (2004) also suggest that, when the legitimating actors are powerful, conform to appropriate genres, and draw on other texts (e.g. master ideas), their texts are likely to embed in the 
discourse. In fact, these characteristics of agency and texts may be interrelated: that is, the less powerful actors are more likely to strive for legitimacy enhancement, conform to the appropriate genre, and draw on macro-cultural discourses. The rationale behind this suggestion is that the actors who have less power and legitimacy are more likely to become the champion of the imported practice in the hope of legitimating themselves through legitimating the practice. In this legitimation process, they are more likely to draw on the power of master ideas which largely involve cultural norms and values. Therefore, the heavy references by corporate managers to the dominant macro-cultural discourses in the Turkish context can be attributed to their enthusiastic efforts, as an emerging actor, to gain a social group identity independent from their bosses by enhancing their social legitimacy. Therefore, we suggest:

Proposition 2: Ethos justifications in the recipient rhetoric of the imported practice are more likely if the legitimating actors themselves strive to enhance their social legitimacy.

Another factor that may influence the recipient rhetoric is to whom the actors legitimate the practice - recipients inside the community in which the actors are also embedded or those outside their community (say the audiences at the national level). Greenwood et al. (2002) imply that institutional entrepreneurs' rhetoric may vary according to their intended recipients. For example, they found that the central professional association within the field of accounting firms in Canada legitimated institutional change to those within the community by exploiting the values already embedded in the profession. In their more recent study on a similar issue, Suddaby and Greenwood (2005) found that $81 \%$ of rhetorical strategies employed by conflicting parties on the emergence of new organizational form appealed to 'reason' (i.e. logos justification). They argued that this might be expected since the actors were predominantly government regulators, accountants, and lawyers who would make appeal to reason. Then, the question becomes what if an institutional change or a practice is to be legitimated to the public, rather than to a specific field, which usually contains various groups with competing values and expectations. We argue that legitimating actors would tend to justify the practice to the public by producing a rhetoric that creates as many associations as possible with macro-cultural discourses common to all the diverse groups. In the Turkish case, we incline to think that in their attempt to justify adoption of TQM to the public, the TUSIAD and KALDER circles may have preferred ethos to logos justifications since references to macro-cultural discourses taken for granted by most people are more exciting, provocative (see Czarniawska and Joerges 1996: 32), and understandable to the public audience than references to, say, statistical quality control techniques in TQM. Hence, our proposition is as follows:

Proposition 3: Ethos justifications in the recipient rhetoric of the imported practice are more likely if the actors promote the practice to the public.

If the propositions above are valid, we argue that the resulting recipient discourse will largely contain ethos appeals drawing on macro-cultural discourses. Such a discourse frequently attributes a quasi-magical status to the imported 
practice as in the case of the TQM discourse in Turkey and quality circles in the US (Abrahamson and Fairchild 1999). This might be a common case because the legitimating actors tend to justify the practice to all types of potential recipients having various and sometimes competing expectations and values by drawing on the macro-cultural discourses appealing to different groups. These efforts may result in a loose and incoherent discourse in the sense that the practice may be signified with diverse and sometimes contradictory signifiers. In the Turkish case, TQM is signified as 'a system of social order', 'a tool for social and economic development', 'a technique for productivity enhancement', and 'a lifestyle'. This incoherent discourse may be more apparent where the legitimating actor lacks formal authority and has a loose structure. In the literature, there has been an emphasis on the role of actors with formal, regulatory or resource power within itself and/or on the other organizations such as the state, professional associations, regulatory bodies, and companies (Cole 1989; Guillén, 1994; Guler et al. 2002; Frenkel 2005). As Greenwood et al. (2002) suggest, the theorization is relatively easy to construct and coherent where the legitimating actor has a formal authority, and the range and intensity of schisms are relatively low in the institutional field. However, as in our case, legitimating actors with no formal authority and hierarchical formal structure such as NGOs may produce rather incoherent texts to legitimate managerial practice. In these advocacy organizations, membership regulations are often loose, and participation is on a voluntary basis (Galvin 2002), which may lead their members to feel relatively free in using different justifications to legitimate the practice to the public. Such a relatively loose membership and participation structure may result in a discourse that has incoherent and sometimes competing justifications. In conclusion, we propose:

Proposition 4: The recipient discourse of an imported practice will be less coherent when legitimating actors have less formal authority and loose structure and/or promote the practice to a wider spectrum of recipients with diverse expectations and values (e.g. to the public).

\section{Conclusions and Final Remarks}

Examining the reconstruction of TQM in Turkey, we have found that the legitimating agencies attempted to legitimate TQM usually in the normative sense by producing ethos justifications emphasizing TQM's congruence with the macrocultural discourses. To a lesser degree, they also justified TQM in the pragmatic sense by drawing on emotional (pathos) and logical (logos) appeals inherent in the source TQM discourse. As a result, they reconstructed TQM as a recipe embracing all solutions to the problems at societal, organizational, and individual levels. Drawing on the implications of the case, we propose that: (1) when a managerial practice is imported to another national context, its reconstruction inevitably involves ethos justifications more than its source discourse; (2) ethos justifications are more likely if actors promoting the practice also strive to enhance their social legitimacy; (3) and more likely if actors promote the practice 
to the public, rather than to their field; and (4) the recipient discourse of the imported practice will be less coherent when the legitimating actors have less formal authority and loose structure and/or they promote the practice to the public.

It might be interesting to note that there are considerable similarities between the rhetorical strategies found in this study and those in Suddaby and Greenwood (2005). For instance, the rhetorical strategies presenting TQM as 'natural consequences of globalization', 'the only alternative', and 'the only way to survive' are echoed in Suddaby and Greenwood's rhetorical category termed 'cosmological', which refers to statements that 'present change as a "natural" consequence, part of orderly evolution of universal laws' (Suddaby and Greenwood 2005: 46). On the other hand, references to the Kemalist ideology, the Japanese model, modernism, and cultural and religious characteristics of Turkish society seem to overlap with Suddaby and Greenwood's 'historical' and 'value-based' categories. Additionally, the statements referring to 'urgent need for radical and nationwide change', 'national quality movement' and 'quality revolution' are echoed in 'teleological' rhetoric, suggesting the instrumental change generated according to a grand plan of human design (Suddaby and Greenwood 2005: 46). These similarities imply, apart from validation of findings, that the actors in different contexts may follow rhetorical strategies similar in kind to legitimize institutional change, regardless of what is legitimized - a managerial practice transferred from abroad or a new organizational form emerging from within a national organizational field. However, due to differences stated in the propositions above, they may emphasize these rhetorical strategies to different degrees: for instance, ethos justifications may be emphasized more in the legitimation of an imported practice whereas logos justifications may be emphasized more in the legitimation of an original practice.

The propositions developed in this study may have significant implications for the institutionalization of imported practices in recipient contexts. As we mentioned earlier, Phillips et al. (2004) suggest that a discourse is more likely to produce institutions if it is more coherent and structured, supported by broader discourses, and not highly contested by competing discourses. However, we suspect that in cross-national reconstruction, the ethos-oriented discourse might be coherent, and produce an institution, even if it is supported by broader discourses and not challenged by competing discourses. This is because there is an inherent tendency in the translation process that generates largely ethos-oriented rhetoric that, in turn, embeds in an incoherent and quasimagical discourse for the imported practice. Such a discourse may produce an initial diffusion among the recipients due to its moral legitimation flavor; nevertheless, this hype may also produce disappointments on the side of adopters whose high expectations from the practice provoked by the ethos-rhetoric are not satisfied with the real application of the practice. As Abrahamson and Fairchild (1999) found, these experiences may also produce critical texts that slow down the further diffusion of the practice. On the other hand, as the meaning of the practice becomes more diffuse, the potential adopters approach it more skeptically, and its legitimacy deteriorates (Zbaracki 1998). Thus, based on Green (2004), Abrahamson and Fairchild (1999), and Zbaracki (1998), we 
can say that throughout its life cycle, the source discourse of a managerial practice may involve a rhetorical sequence of pathos, logos, and ethos, and finally, counter-rhetoric. On the other hand, a managerial practice is usually transferred to the recipient country when it has acquired ethos rhetoric in its source context. This means that in its re-embedding (or re-institutionalization) process in the recipient context, the practice's ethos rhetoric, which has already dominated the source discourse, is further strengthened by factors due to the nature of cross-national reconstruction of a managerial practice. This, in turn, implies that the ethos rhetoric that emerges as the dominant rhetoric of the practice after a relatively long period of diffusion within the source country becomes the introduction rhetoric of that practice in the recipient context. If such an ethos-oriented rhetoric paradoxically produces skepticism about the practice that slows down its further diffusion, then we can expect that the reconstruction of the imported practice in the recipient context is more likely to produce fashions rather than institutions. Because of the ethos-oriented, incoherent, and loosely structured recipient discourse, the transferred practice may dissipate quickly after a period of hype, such as a management fashion.

The propositions and implications of this study could be elaborated by future studies comparing the reconstruction processes of institutionalized and not institutionalized (or 'fashionized') practices in the same recipient country, and those of the same practice in different recipient countries. For a within-country comparison for Turkey, TQM can be compared with holding structure, which was transferred in the early 1960s, not promoted publicly by a specific agent in contrast to the case of TQM, and has been institutionalized gradually and extensively among big business groups largely by mimetic isomorphism mechanisms (Buğra 1994). Another within-country study could focus on the comparison of different discourses produced by different actor groups at the same or different levels in the recipient context in order to understand relative influences of the source discourse, macro-cultural discourses, and actors' legitimacy, authority structure, and audiences they appeal to. It is one of the limitations of the present study that we have focused only on the dominant TQM discourse produced by an elite group at the national level in Turkey. There have also been different TQM reconstructions, although less influential at the national level, by for example, labor unions, workers, and managers at local firms (Y1ldirım 1999). For the between-country comparison, the countries that have different contextual characteristics in terms of legitimating actors and macro-cultural discourses could be selected to compare the influences of these contextual and agential factors on the recipient rhetoric and discourse. For instance, it is one of the limitations of this study that we did not empirically examine the US context and source TQM discourse by collecting and analyzing primary data. Thus, such a recipient-source country comparison study would show us the extent to which various actors different in terms of formal authority, structure, and legitimacy (e.g. governmental agency and NGO) follow different rhetorical strategies that embed in different discourses. This will be a good test of the generalizability of the propositions developed in this study. 


\section{References}

Abrahamson, Eric

1996 'Management fashion'. Academy of Management Review 21/1: 254-285.

Abrahamson, Eric

1997 'The emergence and prevalence of employee management rhetorics: The effects of long waves, labor unions, and turnover, 1875-1992'. Academy of Management Journal 40/3: 491-533.

Abrahamson, Eric, and Gregory Fairchild

1999 'Management fashion: Life cycles, triggers and collective learning processes'.

Administrative

Science Quarterly 44: 491-533.

Academy of Management Review

1994 Special Issue on Total Quality Management, 9/3.

Aguilera, Ruth V., and Alvero CuervoCazurra

2004 'Codes of good governance worldwide: What is the trigger?'. Organization Studies 25/3: 415-443.

Alvarez, José L.

1998 'The sociological tradition and the spread and institutionalization of knowledge for action' in Diffusion and consumption of business knowledge. J. L. Alvarez (ed.), 13-57. London: Macmillan.

Anderson, John C., Manus Rungtusanatham, and Roger G. Schroeder

1994 'A theory of quality management underlying the Deming management method'. Academy of Management Review 19/3: 472-509.

Barley, Stephen R., and Gideon Kunda

1992 'Design and devotion: Surges in rational and normative ideologies of control in managerial discourse'. Administrative Science Quarterly 37: 363-399.
Buğra, Ayşe

1994 State and business in Turkey. Albany, NY: State University of New York Press.

Buğra, Ayş e

1998 'Class, culture, and state: An analysis of interest representation by two Turkish business associations'. International Journal of Middle East Studies 30/4: 521-540.

Carson, Paula Phillips, Patricia A. Lanier, Kerry David Carson, and Brandi N. Guidry 2000 'Clearing a path through the management fashion jungle: Some preliminary trailblazing'. Academy of Management Journal 43/6: 1143-1158.

Casper, Steven, and Bob Hancke

1999 'Global quality norms within national production regimes: ISO 9000 standards in the French and German car industries'. Organization Studies 20/6: 961-986.

Cole, Robert E.

1989 Strategies for learning: Small-group activities in American, Japanese, and Swedish industry. Berkeley, CA: University of California Press.

Czarniawska, Barbara, and Bernward Joerges

1996 'Travel of ideas' in Translating organizational change.

B. Czarniawska and G. Sevon (eds), 13-48. Berlin: de Gruyter.

Dean, James W., Jr, and David E. Bowen

1994 'Management theory and total quality: Improving research and practice through theory development'. Academy of Management Review 19/3: 392-418.

Deming, W. Edwards

1986 Out of crisis. Cambridge, MA: MIT, Center for Advanced Engineering.

DiMaggio, Paul J.

1988 'Interest and agency in institutional theory' in Institutional patterns and organizations. L. G. Zucker (ed.), 3-22. Cambridge, MA: Ballinger. 
Ehrensal, Kenneth N.

1995 'Discourses of global competition: Obscuring the changing labour processes of managerial work'. Journal of Organizational Change Management 8/5: 5-16.

Eralp, Attila

1990 'The politics of Turkish development strategies' in Turkish state, Turkish society. A Finkel and N. Sirman (eds), 219-258. New York: Routledge.

Esenbel, Selçuk, and Inaba Chiharu, editors

2003 The Rising sun and the Turkish crescent: New perspectives on the history of Japanese and Turkish relations. Istanbul: Boğaziçi University Press.

Frenkel, Michal

2005 'The politics of translation: How state-level political relations affect the cross-national travel of management ideas'. Organization 12/2: 275-301.

Galvin, Tiffany L.

2002 'Examining institutional change: Evidence from the founding dynamics of US health care interest associations'. Academy of Management Journal 45/4: 673-696.

Gökşen, Nisan S., and Behlül Üsdiken 2001 'Uniformity and diversity in Turkish business groups: Effects of scale and time of founding'. British Journal of Management 12/4: 325-340.

Gooderham, Paul N., Odd Nordhaug, and Kristen Ringdal

1999 'Institutional and rational determinants of organizational practices: Human resource management in European firms'. Administrative Science Quarterly 44/3: 507-533.

Green, Sandy Edward, Jr

2004 'A rhetorical theory of diffusion'. Academy of Management Review 29/4: 653-669.

Greenwood, Royston, and C. Robert Hinings

1996 'Understanding radical organizational change: Bringing together the old and new institutionalism'. Academy of Management Review 21/4: 1022-1054.
Greenwood, Royston, and Roy Suddaby

2006 'Institutional entrepreneurship in mature fields: The big five accounting firms'. Academy of Management Journal 49/1: 27-48.

Greenwood, Royston, Roy Suddaby, and C. Robert Hinings

2002 'Theorizing change: The role of professional associations in the transformation of institutionalized fields'. Academy of Management Journal 45/1: 58-80.

Guillén, Mauro F.

1994 Models of management: Work, authority, and organization in comparative perspective. Chicago: University of Chicago Press.

Guler, Isin, Mauro. F. Guillén, and John Muir Macpherson

2002 'Global competition, institutions, and the diffusion of organizational practices: The international spread of ISO 9000 quality certificates'. Administrative Science Quarterly 47: 207-232.

Gülfidan, Şebnem

1993 Big business and the state in Turkey: The case of TUSIAD. Istanbul: Boğaziçi University Press.

Hackman, J. Richard, and Ruth Wageman 1995 'Total quality management: Empirical, conceptual, and practical issues'. Administrative Science Quarterly 40: 309-342.

Hasselbladh, Hans, and Jannis Kallinikos

2000 'The project of rationalization: A critique and reappraisal of neo-institutionalism in organization studies'. Organization Studies 21/4: 697-720.

Hechter, Michael

2000 Containing nationalism. Oxford: Oxford University Press.

Heper, Metin

1985 State tradition in Turkey. London: Eothen Press.

Heracleous, Loizos, and M. Barrett

2001 'Organizational change as a discourse: Communicative actions and deep structures in the context of information technology implementation'. Academy of Management Journal 44/4: 755-778. 
Ishikawa, Kaoru

1985 What is total quality control? The Japanese way. Englewood Cliffs, NJ: Prentice Hall.

Jepperson, Ronald L., and John W. Meyer

1991 'The public order and the construction of formal organizations' in The new institutionalism in organizational analysis. W. W. Powell and P. J. DiMaggio (eds), 204-231. Chicago: University of Chicago Press.

Juran, Joseph M

1989 Juran on planning for quality. New York: Free Press.

KALDER

1998 Faaliyet Raporu (Annual Report). Istanbul: Kalder.

Lawrence, Thomas B., and Nelson Phillips

2004 'From Moby Dick to Free Willy: Macro-cultural discourse and institutional entrepreneurship in emerging institutional fields'. Organization 11: 689-711.

Martin, Daniel

1995 'From mechanical engineering to reengineering: Would Taylor be pleased with modern management?'. Journal of Management History 1/2: 38-51.

Meyer, John W., and Brian Rowan

1977 'Institutionalized organizations: Formal structure as myth and ceremony'. American Journal of Sociology 83: 340-363.

Miles, Matthew B., and Michael A.

Huberman

1984 Qualitative data analysis. Newbury Park, CA: Sage.

Morris, Timothy, and Zoë Lancaster

2006 'Translating management ideas'. Organization Studies 27/2: 207-233.

Mueller, Frank, John Sillince, Charles Harvey, and Chris Howorth

2004 A rounded picture is what we need: Rhetorical strategies, arguments, and the negotiation of change in a UK Hospital Trust'. Organization Studies 25/1: 75-93.

Özen, Şükrü

1993 'Political and administrative attitudes of Turkish bureaucrats: An explanatory framework for change and stability'. Turkish Public Administration Annual 17-19: 17-37.
Phillips, Nelson, Thomas B. Lawrence, and Cynthia Hardy

2004 'Discourse and institutions'. Academy of Management Review 29/4: 635-652.

Ryan, Gery W., and H. Russell Bernard 2000 'Data management and analysis methods' in Handbook of qualitative research. N. K. Denzin and Y. S. Lincoln (eds), 769-802. Thousand Oaks, CA: Sage.

Sahlin-Andersson, Kerstin, and Laars Engwall

2002 The expansion of management knowledge: Carriers, ideas and circulation. Stanford, CA: Stanford University Press.

Seo, Myeong-Gu, and W. E. Douglas Creed

2002 'Institutional contradictions, praxis, and institutional change: A dialectical perspective'. Academy of Management Review 27/2: 222-247.

Silverman, David

2000 'Analyzing talk and text' in Handbook of qualitative research. N. K. Denzin and Y. S. Lincoln (eds), 821-834. Thousand Oaks, CA: Sage.

Spencer, Barbara A.

1994 'Models of organization and total quality management: A comparison and critical evaluation'. Academy of Management Review 19/3: 446-471.

Stake, Robert E.

2000 'Case studies' in Handbook of qualitative research. N. K. Denzin and Y. S. Lincoln (eds), 435-454. Thousand Oaks, CA: Sage.

Strang, David, and John. W. Meyer

1994 'Institutional conditions for diffusion' in Institutional environments and organizations. W. R. Scott and J. W. Meyer (eds), 100-112. Thousand Oaks, CA: Sage.

Sturdy, Andrew

2004 'The adoption of management ideas and practices: Theoretical perspectives and possibilities'. Management Learning 35/2: 155-179.

Suchman, Mark. C.

1995 'Managing legitimacy: Strategic and institutional approaches'. Academy of Management Review 20/3: 571-610. 
Suddaby, Roy, and Royston Greenwood

2005 'Rhetorical strategies of legitimacy'. Administrative Science Quarterly 50: 35-67.

Üsdiken, Behlül

1996 'Importing theories of management and organization: The case of Turkish academia'. International Studies of Management and Organization 26/3: 33-46.

$\mathrm{Xu}, \mathrm{Qi}$

1999 'TQM as an arbitrary sign for play: Discourse and transformation'. Organization Studies 20/4: 659-681.
Y1ldırım, Engin

1999 'Modern management techniques in the developing world: The case of TQM and its impact on workers in Turkey'. Work, Employment \& Society 13: 693-709.

Zbaracki, Mark J.

1998 'Rhetoric and reality of total quality management'. Administrative Science Quarterly 43: 602-636.

Zeitz, Gerald, Vikas Mittal, and Brian McAulay

1999 'Distinguishing adoption and entrenchment of management practices: A framework for analysis'. Organization Studies 20/5: 741-776.

\section{Şükrü Özen}

Ümit Berkman
Şükrü Özen (PhD, Gazi University, Ankara) is an Associate Professor of Organization Theory at the Faculty of Economics and Administrative Sciences, Başkent University, Ankara. His main research interests are new institutional theory, diffusion of business knowledge, and discursive action. His most recent works focus on the cross-national transfer of guru knowledge; integration of institutional and social movement theories; and Turkish business systems and managerial culture.

Address: Faculty of Economics and Administrative Sciences, Başkent University, 06530 Bağlıca, Ankara, Turkey.

Email: sozen@baskent.edu.tr

Ümit Berkman ( $\mathrm{PhD}$, Syracuse University, USA) is a Professor of Organization and Management Theory at the Faculty of Business Administration, Bilkent University, Ankara. His main research interests are business ethics, corruption and bribery in administrative systems, and organization development. Recent work has covered a review of Turkish academic literature on the corporate social responsiblity activities of Turkish firms; and Turkish business systems and managerial culture.

Address: Faculty of Business Administration, Bilkent University, 06800 Ankara, Turkey. Email: berkman@bilkent.edu.tr 


\section{Appendix: Documents Used in the Study}

Argüden: Önce Kalite (1998) Kalder Başkanı Dr Yılmaz Argüden'le Söyleşi (interview with Dr Yilmaz Argüden, the President of Kalder). 27: 8-11.

Argun: $\quad$ Önce Kalite (1997) Tanju Argun ile Söyleşhı (interview with Tanju Argun). 19: 18-21.

Gökçe, Ata (1997) 'Toplumsal Sistemler' (Societal Systems). Önce Kalite 19: $22-25$.

Güven, Selim (1994) 'Yorum: Ülkemizde Toplam Kalite Yaklaşımı' Değişen Kalite Anlayışı ve Toplam Kalite Yönetimi Sempozyumu Bildirileri ('Koç; 2000 Project' in TQM: Turkish Perspective, Proceedings of the Symposium on Changing Quality Concept and Total Quality Management), 137-139, 4-5 November 1993, Istanbul: ITU. http://www.kalder.org.tr, accessed 27 September 1999.

KALDER (1999) Toplam Kalite Yönetimi Eğitimi Notları (Total Quality Management Seminar handouts), Istanbul: Kalder.

Kavrakoğlu, Ibrahim (1998) Toplam Kalite Yönetimi (Total Quality Management), Istanbul: Kalder.

Kilitçioğlu: Önce Kalite (1998) Hakan Kilitçioğlu ile Söyleşi (interview with Hakan Kilitçioğlu). 26: 12-14.

Piker: Önce Kalite (1997) Ahmet Piker ile Söyleşi (interview with Ahmet Piker). 19: 15-17.

Sidi, Victor (1994) 'Koç; 2000 Projesi’ Değişen Kalite Anlayışı ve Toplam Kalite Yönetimi Sempozyumu ardından yayımlanan Toplam Kalite Yönetimi Türkiye Perspektifi ('Koç 2000 Project' in TQM: Turkish Perspective, Proceedings of the Symposium on Changing Quality Concept and Total Quality Management), 66-69, 4-5 November 1993, Istanbul: ITU. 